\title{
13 \\ A critical review of the ship investment literature
}

Panayiotis C. Andreou and Isabella Karasamani

\section{Accepted for publication at: The Handbook of Maritime Management.}




\begin{abstract}
This paper provides a critical review of the ship investment literature in the last 30 years following 43 journal articles and book chapters. The review is based on a framework that synthesizes and integrates the literature in terms of timing and viability of shipping investment, raising of funds and managing the investment. Based on this review, a number of promising directions for future research are laid out through the identification of the major contributions and the progress that has been made so far with regards to the broader thematic area of shipping investments, as well as through highlighting important knowledge gaps that could potentially serve as a research agenda for the future.
\end{abstract}




\subsection{Introduction}

Central questions during scientific inquiry in shipping finance have been the ability of firms to identify in time, potentially viable investment opportunities in ships, the ability of firms to raise capital and also the ability of shipping firms to manage the investments and to achieve specific financial objectives. For instance, Kalouptsidi (2014) explores the nature of fluctuations in world bulk shipping by quantifying the impact of time to build and demand uncertainty on investment and prices; Bendall \& Stent (2003) rely on real option analysis to model strategic flexibility planning pertaining to investment decisions under swings in shipping demand driven by periods of uncertainty and declining profitability; and Merikas et al. (2009) analyse the price performance of global shipping initial public offerings (IPOs).

Studies of this nature dealing with the timing, viability, raising of funds and management of investments have been undertaken at various stages over the years giving rise to the need for a review and critique of the expanding and diversified knowledge base of the topic as it continues to develop and to address new and emerging topics that would benefit from a holistic conceptualization and synthesis of the literature to date. As these questions have been investigated for many years, this research domain has matured and the size of its literature has grown, hence a literature review is a necessary step in structuring and developing further the theory in this research field.

The objective of this paper is to identify and review studies of the main pillars of ship investment research and integrate theoretical thinking. An integrative review is composed of critical analysis and examination of the given topic culminating in precipitation of the need for new research. A literature review is essential for providing a sense of focus and a direction for new research. Although no review is completely inclusive, yet the critical review approach we follow allows us to synthesize and integrate the vast and diverse literature on ship investment. In this respect, this paper contributes to the extant literature by 
proceeding with classification of the studies regarding the timing during which the investment is made, the appraisal of the investment and the management of the investment to identify gaps, issues and opportunities for further research and offer new understandings and, possibly, significant reconceptualization of the theme under investigation.

\subsection{Method}

To ensure the achievement of a systematic review of the "ship investment" literature, the method applied two stages as suggested by Alves et al (2016) viz. (1) planning the review which indicates how the systematic approach was planned and (2) conducting the review and analyzing the implications, which sets out the description of how the review was carried out and the systematization of the selected literature.

In conducting a critical review it is important to identify, assess and systematically review all relevant studies using a transparent process that will safeguard replicability (Petticrew and Roberts, 2008, Tranfield et al., 2003). The process is described and entails the paper selection/exclusion criteria and the synthesis and interpretation-based assessment that would ensure a systematic review (Macpherson and Holt, 2007, Thorpe et al, 2005, Tranfield et al., 2003).

Our review relies on information derived from 43 journal articles, books, and book chapters extracted in a four-step procedure. First, we focused on searches from leading maritime journals (the titles are provided in Appendix A.1). We accessed our targeted journals directly from the publishers' website and carefully read abstracts from all published issues since 1984 to identify the most relevant ones. Second, given the multidisciplinary nature of ship investment research, especially with financial economics, we searched via Scopus and Google Scholar for additional economics and finance related journals, including in our information set studies published in the journals listed in appendix A.2. Third, we reviewed shipping and/or shipping finance related books to include the relevant chapters from 
the books listed in appendix A.3. Finally, after reading very carefully each article or book chapter, we kept only those that are related to the scope of our investigation, in particular, the timing and viability of investment, sources of finance, and management of the investment. In addition, we kept book chapters from books that were deemed to have undergone a peerreview process of the same quality as that of an academic journal. 
Table 1

Literature Search Results

This table tabulates the literature search findings resulted from published journal articles. The numbers report articles used in case. Numbers inside the parentheses report relevant percentage $(\%)$ in each case.

\begin{tabular}{|c|c|c|c|c|c|c|c|}
\hline Journal & Empirical & $\begin{array}{l}\text { Event } \\
\text { Study }\end{array}$ & $\begin{array}{l}\text { Case } \\
\text { study }\end{array}$ & $\begin{array}{l}\text { Survey/ } \\
\text { In- depth } \\
\text { Interview }\end{array}$ & Simulations & Theoretical & Total \\
\hline $\begin{array}{l}\text { Maritime Policy and } \\
\text { Management }\end{array}$ & $8(61)$ & $1(8)$ & $0(0)$ & $0(0)$ & $0(0)$ & $4(31)$ & $13(30)$ \\
\hline $\begin{array}{l}\text { Transportation Research } \\
\text { Part E }\end{array}$ & $9(100)$ & $0(0)$ & $0(0)$ & $0(0)$ & $0(0)$ & $0(0)$ & $9(21)$ \\
\hline $\begin{array}{l}\text { The Handbook of Maritime } \\
\text { Economics and Business }\end{array}$ & $0(0)$ & $0(0)$ & $0(0)$ & $0(0)$ & $0(0)$ & $3(100)$ & $3(7)$ \\
\hline Unpublished/ Working Papers & $0(0)$ & $0(0)$ & $0(0)$ & $0(0)$ & $2(100)$ & $0(0)$ & $2(5)$ \\
\hline $\begin{array}{l}\text { International Journal of } \\
\text { Maritime Economics }\end{array}$ & $1(50)$ & $1(50)$ & $0(0)$ & $0(0)$ & $0(0)$ & $0(0)$ & $2(5)$ \\
\hline $\begin{array}{l}\text { Maritime Economics and } \\
\text { Logistics }\end{array}$ & $1(100)$ & $0(0)$ & $0(0)$ & $0(0)$ & $0(0)$ & $0(0)$ & $1(2)$ \\
\hline $\begin{array}{l}\text { Research in Transportation } \\
\text { Economics }\end{array}$ & $1(100)$ & $0(0)$ & $0(0)$ & $0(0)$ & $0(0)$ & $0(0)$ & $1(2)$ \\
\hline $\begin{array}{l}\text { The Asian Journal of Shipping } \\
\text { and Logistics }\end{array}$ & $1(100)$ & $0(0)$ & $0(0)$ & $0(0)$ & $0(0)$ & $0(0)$ & $1(2)$ \\
\hline $\begin{array}{l}\text { Journal of Transport } \\
\text { Economics and Policy }\end{array}$ & $0(0)$ & $0(0)$ & $0(0)$ & $0(0)$ & $1(100)$ & $0(0)$ & $1(2)$ \\
\hline Marine Money Offshore & $1(100)$ & $0(0)$ & $0(0)$ & $0(0)$ & $0(0)$ & $0(0)$ & $1(2)$ \\
\hline $\begin{array}{l}\text { South East European Journal } \\
\text { of Economics and Business }\end{array}$ & $0(0)$ & $0(0)$ & $0(0)$ & $1(100)$ & $0(0)$ & $0(0)$ & $1(2)$ \\
\hline
\end{tabular}




\begin{tabular}{|c|c|c|c|c|c|c|c|}
\hline Transportation Journal & $1(100)$ & $0(0)$ & $0(0)$ & $0(0)$ & $0(0)$ & $0(0)$ & $1(2)$ \\
\hline $\begin{array}{l}\text { Witherbys Publishing \& } \\
\text { Seamanship International }\end{array}$ & $0(0)$ & $0(0)$ & $0(0)$ & $0(0)$ & $0(0)$ & $1(100)$ & $1(2)$ \\
\hline $\begin{array}{l}\text { International Journal of } \\
\text { Financial Services }\end{array}$ & $0(0)$ & $1(100)$ & $0(0)$ & $0(0)$ & $0(0)$ & $0(0)$ & $1(2)$ \\
\hline $\begin{array}{l}\text { Management } \\
\text { Journal of Applied Business } \\
\text { Research }\end{array}$ & $1(100)$ & $0(0)$ & $0(0)$ & $0(0)$ & $0(0)$ & $0(0)$ & $1(2)$ \\
\hline $\begin{array}{l}\text { Journal of Applied Corporate } \\
\text { Finance }\end{array}$ & $0(0)$ & $0(0)$ & $0(0)$ & $0(0)$ & $0(0)$ & $1(100)$ & $1(2)$ \\
\hline $\begin{array}{l}\text { Munich Personal RePEc } \\
\text { Archive }\end{array}$ & $0(0)$ & $0(0)$ & $0(0)$ & $0(0)$ & $0(0)$ & $1(100)$ & $1(2)$ \\
\hline $\begin{array}{l}\text { Industrial Management and } \\
\text { Data Systems }\end{array}$ & $0(0)$ & $0(0)$ & $1(100)$ & $0(0)$ & $0(0)$ & $0(0)$ & $1(2)$ \\
\hline $\begin{array}{l}\text { The American Economic } \\
\text { Review }\end{array}$ & $1(100)$ & $0(0)$ & $0(0)$ & $0(0)$ & $0(0)$ & $0(0)$ & $1(2)$ \\
\hline
\end{tabular}


Table 2

\section{Literature Search Results}

This table tabulates the literature search findings resulted from published journal articles in terms of publication year, data and topic. The numbers report articles used in case. Numbers inside the parentheses report relevant percentage (\%) in each case.

\section{Years and topics \\ Publication years \\ $1980-1989$ \\ $1990-1995$ \\ $1996-2000$ \\ $2001-2005$ \\ $2006-2010$ \\ $2011-2015$}

\section{Data}

Global

US

Europe

Asia

Scandinavia

\section{Topics of ship}

investments

Timing, type and

appraisal

Viability and appraisal

of ship investments

Raising funds for ship purchase

\section{Empirical}

Event
Study

$\begin{array}{ll}0(0) & 0(0) \\ 1(100) & 0(0) \\ 4(80) & 0(0) \\ 4(50) & 1(13) \\ 5(38) & 2(15) \\ 11(85) & 0(0)\end{array}$

$14(78)$

8 (89)

$2(50)$

$1(50)$

$0(0)$

$11(61)$

$1(14)$

13(72)

$1(6)$
$1(11)$
$1(25)$
$0(0)$
$0(0)$

$3(17)$

$0(0)$

$0(0)$

\section{Case stud}

$0(0)$

$0(0)$

$0(0)$

$0(0)$

2 (15)

$0(0)$

$0(0)$

0 (0)

$0(0)$

$0(0)$

1 (100)

1 (6)

1 (14)

$0(0)$
In- depth Interview

$0(0)$

$0(0)$

$0(0)$

$0(0)$

1 (8)

$0(0)$

$0(0)$

$0(0)$

1(25)

$0(0)$

0 (0)

$0(0)$

$0(0)$

3 (17)

18 (42)

2 (11)

$0(0)$

$0(0)$

1 (50)

0 (0)

$0(0)$

3 (43)

2 (29)

7 (16)

0 (0)

4 (22)

$18(42)$ 


\subsection{Ship Investment Review}

In the following sections, we critically review the ship investment literature separately for the three topics of interest, namely, when and how to invest, how to manage the investment and how to raise the funds for the investment. In each case the aim is to provide the structure of the extant studies, their nature and the provision of implications and recommendations for future research.

When and how to invest: market efficiency and ship investments

\subsubsection{When and how to invest: Market efficiency and ship investment}

\subsubsection{Market efficiency}

Second-hand ship trading preserves market competitiveness through the ease in entering or exiting freight markets. Demand and supply in new-building vessels as well as prices are highly depended on cyclical fluctuations. Such fluctuations have at several occasions led to collapses, causing serious financial difficulties and even defaults to shipping firms and shipyards (Andreou et al. ,2014; Tsolakis et al., 2003)

This strand in the literature identified the necessity of investigating whether the markets for second-hand and new-building vessels are efficient and whether assets are priced rationally, since a rejection of the efficient market hypothesis $(\mathrm{EMH})$ may be a sign of arbitrage opportunities. Publications relevant to this component centre on the methodologies employed to test the efficiency of the market for ships. In early work, Strandenes (1984) who utilized a present value framework to explore prices in the dry bulk and tanker sectors, revealed that prices are mainly affected by changes in the long-term equilibrium profits than by changes in operating profits. Under the assumption that current market rates and equilibrium rates reflect ship prices, she concludes that such a finding supports the semirational expectations assumption in the formation of ship prices. In an earlier study Beenstock (1985), under the assumption of rational expectations and efficient markets, employs a 
dynamic general equilibrium model for the determination of ship prices, suggesting that prices are explained by current and expected freight rates and economic activity. Hale and Vanags (1992) report the existence of cointegration between the three-time series of secondhand prices, questioning market efficiency for three sizes of dry bulk second-hand vessels. Extending the Hale and Vanags (1992) method, Glen (1997) tested the informational efficiency for three tanker ship sizes as well as dry bulk ships. Applying the powerful tool of Johansen's maximum likelihood method, the author posed doubts on the existence of efficient markets in the tanker and dry cargo markets. Glen (1997) further argued that even the existence of cointegration does not necessarily mean market inefficiency, if the factors that create the common trends are stochastic in nature. Kavussanos and Alizadeh (2002) extended the Vector Autoregressive models proposed by Campbell and Shiller (1988), and determined the presence of time varying risk premia that rejected the efficient market hypothesis in the markets for new-building and second-hand dry bulk vessels, also supporting the existence of rational bubbles in the formation of ship prices.

A later study by Tsolakis et al. (2003) applied an Autoregressive Model for all ship types and found that second-hand ship prices are largely influenced by new-building prices and time-charter rates in most cases both in the short and long run. The cost of capital appeared to solely affect bulk carriers, while order-book exhibited a negative relationship with the price of second-hand vessels only in the long run and only in large and Panamax tankers. Consistent with the notion that newbuilding prices are cost driven, shipbuilding costs were found to have the highest impact on new-building prices for all ship types, while timecharter rates appeared to influence only a few ship segments. Actual exchange rates do not influence shipbuilding prices directly, but indirectly through cost variations, due to exchange rate fluctuations. Results relating to the order-book, showed that shipyards' extension policy targets at high value ships like tankers rather than bulk carriers. Tsolakis' et al. (2003) results, 
suggested also that newbuilding prices for certain ship types may be partially influenced by asset pricing and speculation.

A daunting issue relates to trading costs and the effects of the illiquid shipping market (e.g., delays in the execution of a buy or sell decision and the deviation from the desired buy or sell price) which are rarely considered in the investigation of price efficiency and would definitely impact returns. Another issue is whether there is a common stochastic trend in the data (e.g., caused by trade growth and costs to asset price behaviour) which could imply that the series are still not forecastable in the long run, even if co-integration exists.

The literature addresses the issue of ship price composition, on testing the efficiency of shipping markets, and on investigating the behaviour of ship prices and volatility. However, there has been lack of comprehensive evidence as to the profitability of sale and purchase decisions of ships based on fundamental analysis. An exception to this is the recent study by Kalouptsidi (2014) who explores the nature of fluctuations in world bulk shipping by quantifying the impact of time to build and demand uncertainty on investment and prices. The author examines the impact of both construction lags and their lengthening in periods of high investment activity, by constructing a dynamic model of ship entry and exit and finds that moving from time-varying to constant to no time to build reduces prices, while significantly increasing both the level and volatility of investment. Future research should also focus on more theoretical and rigorous developments to result into seminal work which obviously could provide a strong basis for furthering this scientific field in terms of understanding better the timing of ship investments; in this respect, studies would have clear implications for policy makers and decision makers alike.

\subsubsection{Ship investments}

Compared to the other areas of shipping investments, mergers and acquisitions (M\&As) is one of the most commonly represented topics in the pool of the examined papers. Further, 
although the prevailing literature in shipping finance concentrated on investment choices of financial assets, shipbuilding cycles and the speculative behaviour characterizing secondhand ship investments due to the long delivery time of new ships, studies turned their attention to the efficiency of new-building and second-hand markets. Second-hand ship trading has a tremendous economic impact on the shipping industry as it facilitates the direct buying and selling of ships and preserves market competitiveness through the ease in entering or exiting freight markets. Similarly, demand and supply in new-building vessels as well as prices are highly depended on cyclical fluctuations. Such fluctuations have on several occasions led to collapses, causing serious financial difficulties and even defaults to shipping firms and shipyards (Tsolakis et al., 2003).

\subsubsection{1Mergers and acquisitions (M\&As)}

The efforts of shipping firms to adapt to the dynamic environment influenced the development of strategies directed to market value enhancement rather than simply profit maximizing. In this context, the last decades have seen an increasing number of (M\&As).

The prevailing theoretical framework of these studies is centred predominantly on the motives and the underlying environmental conditions inducing M\&As (Midoro and Pitto, 2000, Panayides and Gong, 2002b, Brooks and Ritchie, 2006, Yeo, 2013) addressed by the prospect of the combined economic value generated by the merged firm.

Brooks and Ritchie (2006) developed a typology to explain the motives driving M\&As particularly in the transport sector, and to verify whether they are satisfactorily addressed by the scope of the typology. The suggested typology revealed two crucial motives characterizing target-driven acquisitions in the transportation sector (1) financial, e.g. due to debt obligations and (2) redefining of the core business whereby an acquirer would assume activities outside the firm's strategic direction. The second classification in terms of economic value refers to the value-neutral theories which signify the managers' exaggerated 
self-confidence or hubris in deciding upon an acquisition of a target (Roll, 1986). Identifying the variations among countries not only in respect to the frequency of takeover attempts, but also to the possibility of a the merger being friendly or hostile, the presence of cross-border mergers, the premiums offered, and the method of payment i.e. cash or stocks, the literature on shipping M\&As appeared to equally examine the USA market (e.g., Andreou et al., 2012) as well as the global market to avoid potential country specific biases arising from the effects of regulatory and legal constraints (Alexandrou et al., 2014).

Studies on mergers and acquisitions in the shipping industry, while often quite rich and comprehensive, have tended to be largely qualitative in nature being observed in the form of event and case studies of a single merger case and in the form of survey and interview data (Panayides and Gong, 2002b, Syriopoulos and Theotokas, 2007, Solesvik and Westhead, 2010); nonetheless, in certain instances maintaining a quantitative approach for case studies of multiple mergers (Samitas and Kenourgios, 2007, Alexandrou, et al., 2014). More recent studies emerged in the form of panel data analysis seeking for relationships in models linking various hypothesized causal variables to various valuation, proximity and financial measures being analyzed through univariate and multivariate regressions as well as multiple logit and Cox regressions (Andreou, et al., 2012, Merikas, et al., 2011, Das, 2011, Yeo, 2013, Alexandrou et al., 2014).

In general, the inference from this strand of literature suggest that M\&As in shipping add to the value of the firms that decide to pursue them (Andreou et al., 2012). Studies indicated that in general stock prices rise rapidly on the announcement of the proposed consolidation, a fact that is long anticipated by the industry, and in addition the share price of the target companies increases more than the share price of the bidder companies' due to the announcement of the major strategic move (Panayides and Gong, 2002a). Additionally, Samitas and Kenourgios (2007), results revealed that M\&As have a direct positive impact on 
shipping firms' stock prices and increase financial value; these firms become also larger in terms of the deadweight tonnage terms due to the overall fleet expansion. Brooks and Ritchie (2006) reviewed all mergers and acquisitions globally and presented a consolidation tendency in the shipping sector while arguing that the industry does not notably differ from other sectors of the transport industry. Brooks and Ritchie (2006) suggest considering targets' motivations in addition to the usual focus on acquirer motives, and to confer further attention on the geographic dimension and minority acquisitions. The geographic component of mergers was addressed at a later study by Yeo (2013) who stressed the importance of geographical closeness as a noteworthy reason for consolidations due to the low costs of acquiring information regarding targets. Yeo (2013) also inferred that larger targets appear to be more attractive for inter-continental consolidations because of economies of scale, confirming to a certain extent that the prime motivation of M\&As is to accomplish synergy effects.

Future research is required to provide further evidence regarding the changing motivations behind merger activity which are highly influenced by the prevailing environmental factors and appear frequently as a natural response to various elements in the industry structure or to distinct phases of the business cycle. In addition, apart from a few exceptions, studies generally use case analysis and small samples, suggesting the need for new studies with long-term data. In this respect, longitudinal rather than cross-sectional studies will provide additional insights relating to time-specific issues, and the scale, nature, processes, costs and benefits associated with alternative inter-firm investment strategies. Further, future research should also investigate the determinants of long run returns/operating performance of mergers and acquisitions and investigate the possible differential valuation effects in the supply chain (i.e., upstream or downstream in the transportation chain). Strategic motives, not only from the side of the acquirer but also from the target should also 
be looked at. Finally, current literature M\&As totally lacks evidence relating to the motives behind the wealth effects and economic synergies that emerge from fleet diversification and the timing of acquisitions.

\subsubsection{Viability and appraisal of ship investments}

Conventional literature on modelling ship prices primarily based its analysis on general and partial equilibrium models and employed structural relations between certain variables including order-book, new-building deliveries, scrapping rates, freight rates, and bunker prices (for example Strandenes, 1984, Beenstock and Vergottis, 1989). Other literature (Bendall and Stent, 2003, Bendall and Stent 2004, Bendall and Stent, 2007, Bendall, 2010, Axarloglou et al., 2013) recognizing the characteristics of the shipping industry argued for real options analysis for establishing ship prices under uncertainty and other market fluctuations. Studies dedicated on real options analysis referred to Black and Scholes (1973), Merton (1973) and the binomial approach of Cox, Ross and Rubinstein (1979) for pricing financial options. In this respect, a real option is the right, but not the obligation, to take a future action which will alter the value of an investment. Following these grounds, the analysis is based on proposed scenarios with hypothetical examples distinguishing between static and flexible investment strategies and simulation analysis (e.g., Bendall and Stent 2003, 2004, 2007).

A prerequisite for real options analysis is operational flexibility in managing ships, entailing flexibility in entering or exiting the market, employing vessels in the spot or the time-charter market, moving between lay-up and trading statuses, expanding operations, and switching inputs or outputs (Bendall and Stent, 2003, 2004, 2007). As a result, this strand of literature firmly supported that shipping is dependent upon many changing variables which stipulate ongoing strategic planning assessments to adjust to differing economic cycles. 
The empirical part of most of the studies dealing with real options analysis utilized case studies with proposed investments (Bendall and Stent, 2003, 2004, 2007). These scenarios were based on actual trade data and constituted appropriate settings to understand investment dilemmas encountered by ship-owners showing the efficacy of real options analysis as an appropriate valuation method. To value the proposed strategies, simulation models are built to represent underlying assets and provide estimates of present values which were eventually used as market prices. The studies also provide estimates of respective volatilities and correlations which are used to model the evolution of prices in a second step when options are valued.

Bendall and Stent (2003) argued that as with other sectors, shipping firms operate in a volatile market environment; hence, choices directed to trade rationalization can significantly impact the firm's long-term competitive posture. This would suggest that at times of depressed market conditions, shipping firms should be flexible to exit the market and re-enter at favourable conditions. Because of the high uncertainty in the shipping market and the costs associated with such a strategy, exiting the market until conditions improve would pose a threat of losing market share from competitors. As a result, such a strategy cannot simply be evaluated in terms of exiting and entering the market and, more importantly, traditional capital budgeting techniques fail to assimilate the arrival of new information into their investment assessments (Bendall and Stent, 2003, 2004, 2007). Consequently, the passive or static nature of traditional discounted cash flows (DCF) and net present value (NPV) analysis is regarded as of limited application in the valuation of projects which require management flexibility to adapt to future contingencies.

Bendall and Stent $(2003,2004,2007)$ argued that real options analysis can serve as a more appropriate technique because it values explicitly operational flexibility, treating it like a financial option with the use of non-arbitrage. It is then added to the present value of the 
original strategy to give the present value of the flexible strategy. Hence, management does not assess investments as mutually exclusive options, but rather, as a switching option exercise. This framework enables management to decide between market entrance and exit, operating in spot and period time-charter, and switching between lay-up and trading; thus, it facilitates the exchange of one risky income stream related to a strategy for that of another.

However, the limited extant literature also suffers from methodological limitations. For instance, sample sizes are rather limited to a very small number of ships or even to only one ship. In addition, geographic coverage is non-existent and the analysis referred only to the countries the hypothetical service would be based, which may be very restrictive. Future research should also accommodate the decision of managers to postpone the commitment of their resources for later-on, and thus pursue some extra flexibility, thus allowing managers to reverse their commitment of resources before the expiration time of the projects. Future research may also consider severe demand shocks such as the unprecedented economic crisis.

Finally, the implications of the real options framework should ultimately validate the managerial decision-making process. In this vein, only the study by Axarloglou, et al. (2013) employed a real options approach to theoretically determine the way managers and shipowners operate their vessels by chartering them for different ranges of time spans. This decision-making directly influences the variations in the volume of voyage and the prospective fixtures of time- charters; thus, it highly impacts the spread between voyage and time-charter rates. Axarloglou et al. (2013) derived the spread between voyage and timecharter rates, illustrating that when a time-charter contract is compared to a stream of voyage contracts of the same time-period, several separate real options appear that cover a common time horizon with the time-charter contract. Empirical evidence suggested that managers or ship-owners decide upon expending their firm's resources for a short period (long period) during boom market conditions in order to maintain a flexible (commitment) approach and 
take advantage of impending opportunities whilst charterers behaved in the opposite manner. Future research should follow a similar paradigm to provide well justified empirical inferences which would give support to the real option models.

\subsubsection{Raising funds for ship purchase}

The financing perspective remains a momentous pillar for shipping firms which are required to tie internal and external financing decisions to the intensive capital requirements related to the underlying real assets and the cyclical and volatile nature of the industry. Hence, the financing pillar defines its own sub-universe in shipping finance with three primary areas that are critically examined in this section; capital structure, bond financing and initial public offerings.

\subsubsection{Capital structure}

The preference of bank finance and capital markets as dominant options for financing shipping firms can be explained by the central financial theoretical perspective of the pecking order theory; yet, the idiosyncratic conditions of the industry should not be undermined (Grammenos and Papapostolou, 2012). Shipping companies have come through two stages that could possibly explain capital structure choices; in the 1990s, the pecking order theory seems to justify shipping firms' financing preferences, while for 2000 and onwards the market timing theory seems to better explain these preferences (Grammenos and Papapostolou, 2012). The market timing theory seemed to gain some merit especially for the period of 2003-2010 when the capital markets experienced a wave of initial public and secondary offerings by shipping firms as well as increasing tendencies in high-yield bonds issuances. This is indicative of the fact that preference in financing is dependent upon the firm's perception of the costs of debt and equity in conjunction with the industry's specific characteristics. 
Merikas, et al. (2011), suggested that a shipping firm's capital structure should be determined in conjunction with its commercial strategy. Thus, the decision of whether firms will operate their vessels in period charter market or the spot charter market should be dependent on the corporate risk profile (market risk plus financial risk) adopted by the firm. Time charter commercial strategies which assume lower market risks are, therefore, more likely to appear in highly levered capital structures, while firms exposing spot market profiles will tend to adopt a debt free capital structure with low financial risk. The highly cyclical macroeconomic environment and its impact on freight rate volatility and cash flow uncertainty inevitably make market risk a factor constantly demanding monitoring. In addition the continuous and intense capital requirements of the industry endorse a shift towards debt markets. An additional way to determine the shipping firm's capital structure is by assessing how the cyclicality on the asset side of the balance sheet affects the liability side. The high volatility of asset values of shipping companies compared to non-shipping counterparts (Dobretz et al., 2013), along with the high operational leverage and financial leverage characterizing the industry (Kavussanos and Visvikis, 2006), point to the vulnerability of these firms to vessel price risks. Because of high costs of financial distress, shipping firms incur large costs diverging from the target leverage ratios. Nonetheless, the optimality of the past excessive leverage ratios should be an issue of reconsideration since the limited asset redeployment ability in recession times along with the high regulatory requirements imposed to shipping banks will increase the need for equity financing, and as a result, it will decrease expected returns to equity in the industry (Albertijn et al., 2011, Dobretz et al., 2013, Kavussanos and Visvikis, 2006).

The global capital markets have become a valid option for shipping firms, decisions made to correspond to the industry's heavy reliance on capital, either with debt or equity are critical in market value creation. Studies pertinent to the capital structure of shipping firms 
are limited in number; yet, they appear to provide an adequate starting point in terms of magnitude and depth of investigation, hence cultivating a solid ground for future research in the area. These studies identified the aforesaid factors and primarily attempted to tie capital structure issues to the intensive capital requirements related to the underlying real assets, which are directly related to increased financial risks and therefore possible adverse results. To determine the factors affecting the capital structure of shipping firms, studies concentrated both on smaller samples focusing solely on US listed firms for a narrow time period, providing results through correlational inferences (Merikas et al., 2011), as well as on global firms analyzing rather large panels of data and enhancing the analysis through different dynamic panel estimators (Drobetz et al., 2013).

The central theoretical perspectives used to examine the capital structure of shipping firms predominantly discussed four prominent theories; the trade-off theory (Myers, 1977, Jensen and Meckling, 1976, Jensen, 1986), the shipping corporate risk trade-off hypothesis (Merikas et al., 2011), the pecking order Theory (Myers 1984, 2001, Myers and Majiluf 1984), and the market timing theory (Baker and Wurgler, 2002). Regarding the decision to raise funds externally, through either equity or debt, discussions pertinent to the trade-off theory may need to be altered to suit the industry's peculiarities. For instance, the effective tax rate becomes negligible in many countries which have either offered certain tax incentives to relax the tax liability of shipping firms or have established a tonnage tax regime, where the payable tax is based on the tonnage of the vessel and not on accounting figures realized from vessel exploitation. Often shipping firms select to position their operations in those countries offering tax efficient regimes. Future studies should take into account these elements and revisit the capital structure in the shipping industry. Regarding the pecking order theory, in the financial economics literature it has experienced a time of supremacy around the 1990s, but its' supposed drivers are still at odds, especially during economic 
downturns (Huang and Ritter, 2009); more recently the market timing theory seems to better explain capital structure choices. The effect of the exceedingly cyclical macroeconomic environment of shipping firms on freight rates and cash flow uncertainty as well as the observed problem of over-leverage make the overall corporate risk of the firm a burning issue in shipping corporate risk management as it increases the probability of financial distress and impairs financial flexibility. Therefore, future studies should revisit the capital structure choices since recent periods provide a fresh domain for investigation and perform a horserace of the four prominent theories.

Future studies should also provide more in-depth multivariate analysis making efforts to establish causal relationships and moving forward from the extant attempts to empirically investigate hypotheses through a correlational approach establishing only statistical associations, while at the same time, they should employ global datasets which would result into large sample sizes covering longer time periods. Finally, as suggested by Merikas, et al. (2011) future research should also take into account that shipping firm's capital structure should be determined in conjunction with its commercial strategy.

\subsubsection{Bonds financing}

Studies exploring the bond dimension of shipping financing mainly discussed the corporate and investment perspective of bonds. The corporate perspective entailed a comparison of bond financing with traditional bank finance and equity. This perspective deems bond financing as an advantageous financing instrument due to the positive cash flow effect resulting from the non-amortization of interest, the long periods of coupon repayment, and the possibility of converting the bond into equity which potentially does not require any repayment at all (Grammenos et al., 2008, Grammenos and Arkoulis, 2003, Grammenos, et al., 2007). The investment perspective of bonds referred to the investor whose perception on shipping bonds partly stems from the assessments done by rating agencies providing an 
indication of the default risk in bonds. For that reason, most of the studies utilized credit ratings as one key factor in their analysis since credit ratings are intended to reveal the likelihood that a firm will repay its debt on time (Grammenos and Arkoulis, 2003, Grammenos et al., 2007, Grammenos et al., 2008).

The major factors that may have inclined many shipping firms to issue equity have also influenced these firms to shift or combine traditional banking finance with private placements and public issues of debt over the last 20 years. The reports that began to emerge after the early dismissal of bond issues in 2000's anticipated that the shipping industry will need considerable capital requirements resulting from increasing trade flows and ageing fleets. The early dismissals were attributed to the high coupon requirements amplified by the speculative ratings of shipping bonds ascribed by the rating agencies. According to Leggate (2000), these issues conveyed that bond finance largely depends on the perception of the shipping industry by the investment community. The shipping industry appears weak in promoting investor confidence; nonetheless, investors seem to have a more optimistic stance than credit agencies. A good indication of this phenomenon can be found in defaulted bonds which have experienced increased prices and falling yields since default. Fridson and Garman (1998) argue further that this difference in the perception on leverage and market conditions between credit agencies and the market when assessing and pricing high yield bonds, gives rise to agency conflicts between the agencies and their customers comprised by shipping firms.

Despite the reduction in the numbers of shipping high yield bond issues after 1999 due to the high number of defaults of shipping companies, the market has seen an increase of new issues mainly because of the strong shipping market. Primary and secondary dynamics of yield premia are of key importance both for the investment community since information on changes in yield premia can be used for investment and asset allocation purposes, as well as for shipping firms who need bond financing to keep up with intensified capital requirements. 
Credit rating is the major determinant of the yield premia on primary pricing (Grammenos and Arkoulis, 2003, Fridson and Garman, 1998, Garman, 2000) and financial leverage as well as shipping market conditions are found to explain a significant part of the price variability (Fridson and Garman, 1998). The drivers of the spreads of global cargo carrying high yield bonds- the only sample being investigated separately up to now- are found to be liquidity of the bond issue, market-wide volatility, cyclical bond factors, freight earnings and the credit rating of the issue (Kavussanos and Tsouknidis, 2014). Such a focus on a specific shipping sub-sector is important because of the distinct cycles underlying different shipping sectors, which can affect the ability of a bond issuer to meet loan obligations.

Seasoned high yield bond premia appear to be related to macroeconomic factors, i.e. the ten-year Treasuries as well as the Merrill Lynch single-B Index (Grammenos et al., 2007). Furthermore, seasoned high yield premiums seem to be larger the lower the credit rating and the lower the earnings in the shipping market, and wider throughout the passage of time until maturity. The credit rating's significance is marked as dominant; yet, the shipping market proxied by earnings — also captures an important share in determining the spread. This denotes that investors not only asses the shipping market but they also consider the credit ratings while deciding upon investments in shipping high yield bonds (Grammenos et al., 2007).

After the 1999 recession in the shipping market many shipping companies who operated their fleet mainly in the spot market were found incapable of meeting their debt obligations in the US high yield bond market (Grammenos et al., 2008). Grammenos et al. (2008), highlighted certain financial variables that can, in fact, provide a signal on issues that have a high likelihood to default. Specifically, higher gearing levels are found to be associated with increased probabilities of default when these levels reach $65 \%$ or more, and if the amount to be raised surpasses total assets by $80 \%$. On the contrary, working capital over 
total assets ratio, and retained earnings over total assets ratio as well as the industry specific variable capturing of shipping market conditions at the time of issuance seem to negatively predict the probability of default.

In conclusion, the use of panel methodology is highlighted in investigating the determinants of credit spread changes in the bond financing frame. Also, geographical coverage is rather broad and standard compared to the other strands of literature, focusing on global, EU and US bond issues. These studies draw on the benefits and limitations of panel data and conclude that the shipping industry entails a heterogeneous group of companies exhibiting variables which are difficult to measure and quantify monthly. Thus, it is highly supported that any future attempt to capture this heterogeneity should be done by the utilization of a fixed effects model (Grammenos et al., 2008). As suggested by Kavussanos and Tsouknidis (2014) the technical handling of panel data estimations is a critical aspect driving research findings in shipping bond spreads. Extensive use of wider samples to global bonds and longer time periods capturing complete shipping business cycles are also factors that received limited attention in the literature but are considered as key in providing insights with respect to shipping bond financing (Kavussanos and Tsouknidis, 2014). Moreover, future research is called to conduct a careful selection of the sample of the shipping bonds to make sure that the variable of freight earnings adequately reflects the returns of the bond issuer. Such a section is deemed crucial as investors tend to evaluate the ability of a firm to repay its loans by assessing the freight market segment the firm operates, its cyclicality, and its income generation (Kavussanos and Tsouknidis, 2014).

\subsubsection{IPOs}

Regardless of their critical role in investment funding, equity markets have traditionally demonstrated limited contribution in shipping finance. This is attributed to the perseverance of these firms on a family-owned structure, the disinclination of ship-owners to disseminate 
firm control, and the lack of transparency of important firm information. Moreover, as highlighted by Kavussanos and Marcoulis (2000b), the perception of the investment community regarding the riskiness of shipping stocks compared to other stocks, largely due to the highly volatile environment of the industry in which these firms operate further added to the stock market abstinence of shipping firms. Recently, however, the over-leverage issue along with the bank difficulties in providing adequate capital on a timely manner and in meeting the ever increasing legal requirements and tightening credit facilities; the elevated vessel prices; the demands for larger vessel sizes; the structural adjustments of shipping firms; the appetite for greater visibility and prestige to attract institutional and private investors; and the preference to international capital markets expressed by younger generations of ship-owners constitute some of the reasons that shifted the interest of several shipping firms from the traditional wherewithal of financing to equity financing and global markets (Sambracos and Maniati, 2013, Grammenos and Papapostolou, 2012, Syriopoulos, 2010).

Motives that have been identified to urge shipping firms to IPO issues included vessel acquisition, asset play, and debt repayment. Debt repayment appeared to induce firms that were larger than those induced by vessel acquisition purposes (Grammenos and Marcoulis, 1996). Factors taken into consideration for IPO stock performance vary from gross proceeds of the IPO issue, to firm size and age, equity stake offered, and fleet age, with gearing level being the most important amongst all. IPO performance is mainly assessed with short-term and long-term abnormal returns. These include the percentage change in the first day closing price relative to the offer price for short-term abnormal returns, whilst for long-term returns benchmarks employed are the cumulative average returns (CARs), the buy-and-hold abnormal returns (BHARs) and the Fama-French (1996a) three-factor (FF3F) model. It generally seems that there is a declining over-performance as moving towards six months 
after listing. Moreover, consistent with information signalling theories, under-pricing is found to positively relate to the age of the firm implying a type of private valuation undertaken by ship-owners into the age of the firm before going public (Merikas et al., 2009). Other features that elucidate first trading day returns relate to the reputation of the stock market and the IPO market conditions prevailing at the time of the issue, while the reputation of the underwriter appears to negatively affect under-pricing. US stock exchanges, however, seem to suffer from a less severe under-pricing on initial trading day (Merikas et al., 2010), indicating extraordinary maturity levels in the shipping sector; whilst this difference in the results compared to global IPOs for one-, two-, three-year holding period returns pose doubts on whether investing in US shipping IPOs is a guaranteed investment by those maintaining a long-term investment philosophy.

With regards to the probability of US shipping IPOs being under-priced, the main focus should essentially be on the existence of asymmetric information. Under-pricing often arises from informational asymmetry between market players; specifically, the issuing firm, the underwriter, the initial investors, and the secondary market investors. In this respect, Cullinane and Gong (2002) focused on the hypothesis of the divergence of opinion originally proposed by Miller (1977), which has received limited attention. The hypothesis of the divergence of opinion assumes that mis-pricing results from the heterogeneity in investors estimates of the intrinsic value and the expected returns of unseasoned equity issues. Naturally, the divergence of opinion would be more pronounced during the stock's first issuance. Cullinane and Gong (2002) argued that in the context of transportation IPOs, it would seem that Miller's (1977) hypothesis of the divergence of opinion is particularly relevant, a conclusion that sits well with the notion that in the shipping IPOs, it is rational to anticipate higher initial day returns since there exists higher ex ante uncertainty as to their intrinsic values. In similar vein, Grammenos and Papapostolou (2012) evinced that there is no 
information asymmetry between participants in shipping IPOs and that readily available public information prior to the IPO is partially adjusted into the final offer price. Underwriters of shipping IPOs seem to compensate private or institutional investors for disclosing their information about the issuing company in the registration period, and this compensation is reflected in the form of partial adjustment in the final offer price.

Regarding IPOs, the number of publications concentrating on this thematic area has been limited in number; nevertheless, the rate is increasing. It seems that the increasing presence of shipping firms in the capital markets and more particularly in the US markets has attracted considerable interest in recent research. To understand the shipping IPO market in depth, additional research should concentrate on the share allocation to private and institutional investors. These investors are looking for alternative investments; thus, a comprehensive analysis of stock volatility for appropriate portfolio management and efficient asset allocation, as well as firm valuation is a crucial aspect in shipping financing. Merikas et al. (2009), suggest the search into three categories of allocation mechanisms; fixed-price offerings, auctions and book building. Further studies may also concentrate on the accuracy of earning forecasts. Knowing that investors rely on the forecasts provided in the prospectuses of IPO firms to subscribe to the new issue or to invest on the first day of trading, the accuracy of such a forecast is vital (Chen et al., 2001). Research should be produced with the employment of error metrics to examine forecast accuracy of the shipping sector.

The puzzling evidence with respect to the buy and hold returns that US listed shipping IPOs experience, should be examined in conjunction with the unique characteristics of the shipping industry including sophistication, innovation, and complexity (Merikas et al., 2010). Many critical factors should be taken into consideration, including the derived nature of the demand for shipping services (which is sensitive to economic growth), the idiosyncratic characteristics of the shipping industry, and the cyclicality of freight rates and vessel prices. 
Moreover, although most of the IPOs are introduced in the form of cross-listings, this particularity has not been given the adequate attention in the literature of shipping IPOs. It appears that under favourable prevailing economy, equity market and industry conditions at the time of the IPO decision, cross listed IPOs enjoy unexpected range of benefits, including corporate image enhancement, wider reach of existing and potential stockholders as well as greater bargaining power over their creditors (Mourdoukoutas and Stefanides, 2007). As the market matures, researchers should examine IPOs of such a regime with reference to the appropriate venues to list shares, to the timing of the listing, and to indirect effects of the IPO other than the direct outcome of immediate capital growth.

The empirical approaches examined in the prevailing literature on shipping IPOs vary from in-depth interviews and surveys (questionnaires) establishing associations between the variables examined (Mourdoukoutas and Stefanides, 2009), to standard finance methodologies for assessing the existence and scale of mispricing by computing average initial day raw returns by place of listing as well as by nature of service and by group (freight v. passenger) (Cullinane and Gong, 2002), cross sectional regressions in short and post listing returns (Merikas et al., 2009; Merikas et al., 2010), and logit techniques which assigned score to each firm by weighting the independent variables to determine the probability of shipping IPOs being underpriced (Grammenos and Papapostolou, 2012). In addition, the geographic orientation of these publications appeared to be broadly skewed. Only two papers reviewed are based on samples of US listed shipping firms. The rest of the papers vary in geographic focus, concentrating on samples of shipping IPOs in global stock exchanges, on transportation companies that went public in the Chinese mainland and Hong Kong, and on Greek firms choosing to be listed in US stock exchanges. The coverage of topic areas relative to the articles summarized in this section is relatively narrow. Under-pricing is the most 
commonly represented topic, complemented by factors that may explain first trading day returns.

Unlike other areas of shipping finance research, recent studies in shipping IPOs not only attempt to use long periods of examination and the geographical spectrum, but also to incorporate aftermarket returns for shipping IPOs. These studies take into account short- and long-term performance and they unveiled a chronological progress, enriching already researched subject matters while shedding light on new aspects of the performance of shipping IPOs. Further, these studies (Merikas et al., 2009, Merikas et al. 2010, Grammenos and Papapostolou, 2012) displayed unanimous interest in exploiting specific market or firm characteristics such as the underwriter's reputation, the size of the IPO, the reputation of the stock exchange in which the shipping IPO occurred, and the period of listing (defined as hot or cold in terms of cyclical patterns in the IPO market). More research is required on the allocation of shares to institutional and individual investors that could inform the general literature on the allocation mechanisms between fixed-price offerings, auctions and book building. In addition, the literature needs to also consider seasoned equity offerings (SEOs), which constitute another means of equity financing following a firm's IPO.

\subsubsection{Conclusion}

We identified 43 studies on the timing, viability, raising of funds, and management of shipping investments, evidence that academic research recognizes the prominence of this topic in the broader area of shipping finance. This research stream gains from theoretical as well as applied perspectives, which complement and antagonize based on the particular topic and methodology. A key goal for future research should be to examine fields of overlap and omission among the pertinent studies, with special emphasis on their applicability on the highly cyclical and notoriously volatile shipping environment. Second, although the trend towards empirical quantitative analysis is obvious in the studies examined, an extensive focus 
on methodological issues with regards to these studies is required so that research in the field facilitates both the utility and comparability of future work. Lastly, the focus of earlier work needs to be more diverse emphasizing a more integrative picture of what has been done in the past and covering geographic spheres in a more proportionate trend. As it is emphasized in the study, what we offer is not an exhaustive list of the factors that influence shipping investments. By integrating prior work and critically identifying promising research gaps we hope to stimulate further research on the topic. 


\section{References}

Albertijn, S., Bessler, W. and Drobetz, W. (2011) Financing shipping companies and shipping operations: A risk-management perspective. Journal of Applied Corporate Finance 23(4): 70-82.

Alexandrou, G., Gounopoulos, D. and Thomas, H.M. (2014) Mergers and acquisitions in shipping. Transportation Research Part E: Logistics and Transportation Review 61: 212-234.

Alves, H., Fernandes, C. and Raposo, M. (2016) Social media marketing: A literature review and implications. Psychology \& Marketing 33(12): 1029-1038.

Andreou, P.C., Louca, C. and Panayides, P.M. (2012) Valuation effects of mergers and acquisitions in freight transportation. Transportation Research Part E: Logistics and Transportation Review 48(6):1221-1234.

Andreou, P.C., Louca, C. and Panayides, P.M. (2014) Corporate governance, financial management decisions and firm performance: Evidence from the maritime industry. Transp77ortation Research Part E: Logistics and Transportation Review 63: 59-78.

Axarloglou, K., Visvikis, I. and Zarkos, S. (2013) The time dimension and value of flexibility in resource allocation: The case of the maritime industry. Transportation Research Part E: Logistics and Transportation Review 52:35-48.

Baker, M. and Wurgler, J. (2002) Market timing and capital structure. The Journal of Finance 57(1): 1-32.

Beenstock, M. (1985) A theory of ship prices. Maritime Policy and Management 12(3): 215225.

Beenstock, M. and Vergottis, A. (1989) An econometric model of the world tanker market. Journal of Transport Economics and Policy. 23(3): 263-280.

Bendall, H. (2010) Valuing maritime investments with real options: The right course to chart. In: C.Th. Grammenos (ed.) The Handbook of Maritime Economics and Business $2^{\text {nd }}$ ed.. London: Lloyd's List, pp. 683-708.

Bendall, H. and Stent, A.F. (2003) Investment strategies in market uncertainty. Maritime Policy \& Management 30(4): 293-303.

Bendall, H.B. and Stent, A.F. (2004) Ship investment under uncertainty: a real option approach. In University of Otago Department of Finance Seminar Series.

Bendall, H.B. and Stent, A.F. (2007) Maritime investment strategies with a portfolio of real options. Maritime Policy \& Management 34(5): 441-452.

Black, F. and Scholes, M. (1973) The pricing of options and corporate liabilities. The Journal of Political Economy, 81(3): 637-654. 
Brooks, M.R., and Ritchie, P. (2006) Mergers and acquisitions in the maritime transport industry 1996-2000. Transportation Journal 45(2): 7-22.

Campbell, J.Y. and Shiller, R.J. (1988) Stock prices, earnings and expected dividends. The Journal of Finance 43(3): 661-676

Cox, J.C., Ross, S.A. and Rubinstein, M. (1979) Option pricing: A simplified approach. Journal of Financial Economics 7(3): 229-263.

Cullinane, K. and Gong, X. (2002) The mispricing of transportation initial public offerings in the Chinese mainland and Hong Kong. Maritime Policy \& Management 29(2): 107-118.

Chen, G., Firth, M. and Krishnan, G.V. (2001) Earnings forecast errors in IPO prospectuses and their associations with initial stock returns. Journal of Multinational Financial Management 11(2): 225-240.

Das, S.S. (2011) To partner or to acquire? A longitudinal study of alliances in the shipping industry. Maritime Policy \& Management 38(2): 111-128.

Drobetz, W., Gounopoulos, D., Merikas, A. and Schröder, H. (2013) Capital structure decisions of globally-listed shipping companies. Transportation Research Part E: Logistics and Transportation Review 52: 49-76.

Fama, E.F. and French, K.R. (1996) Multifactor explanations of asset pricing anomalies. The Journal of Finance 51(1): 55-84.

Fridson, M.S. and Garman, C.M. (1998) Determinants of spreads on new high-yield bonds. Financial Analysts Journal 54(2): 28-39.

Garman, C. M. (2000) Pricing European high-yield new issues. The Journal of Fixed Income, 9(4): 35-42.

Glen, D.R. (1997) The market for second-hand ships: Further results on efficiency using cointegration analysis. Maritime Policy and Management 24(3): 245-260.

Grammenos, C. (2010) Revisiting credit risk, analysis and policy in bank shipping finance. The Handbook of Maritime Economics and Business, London: Lloyd's List, pp.777-810.

Grammenos, C.T., Alizadeh, A.H. and Papapostolou, N.C. (2007) Factors affecting the dynamics of yield premia on shipping seasoned high yield bonds. Transportation Research Part E: Logistics and Transportation Review 43(5): 549-564.

Grammenos, C.T. and Arkoulis, A.G. (2003) Determinants of spreads on new high yield bonds of shipping companies. Transportation Research Part E: Logistics and Transportation Review 39(6): 459-471.

Grammenos, C.T., Nomikos, N.K. and Papapostolou, N.C. (2008) Estimating the probability of default for shipping high yield bond issues. Transportation Research Part E: Logistics and Transportation Review 44(6): 1123-1138. 
Grammenos, C.T. and Marcoulis, S. (1996) Shipping Initial Public Offerings: A Cross Country Analysis. Empirical Issues in Raising Equity Capital. Oxford: Elsevier, pp.379-400.

Grammenos, C.T. and Papapostolou, N.C. (2012) US shipping initial public offerings: Do prospectus and market information matter? Transportation Research Part E: Logistics and Transportation Review 48(1): 276-295.

Hale, C. and Vanags, A. (1992) The market for second-hand ships: some results on efficiency using cointegration. Maritime Policy \& Management 19(1): 31-39.

Huang, R. and Ritter, J.R. (2009). Testing theories of capital structure and estimating the speed of adjustment. Journal of Financial and Quantitative analysis 44(02): 237-271.

Jensen, M.C. (1986) Agency cost of free cash flow, corporate finance, and takeovers. Corporate Finance and Takeovers. American Economic Review 76(2): 323-329.

Jensen, M.C. and Meckling, W.H. (1976) Theory of the firm: Managerial behavior, agency costs and ownership structure. Journal of Financial Economics 3(4): 305-360.

Kalouptsidi, M. (2014) Time to build and fluctuations in bulk shipping. The American Economic Review 104(2): 564-608.

Kavussanos, M.G. and Alizadeh, A.H., (2002) Efficient pricing of ships in the dry bulk sector of the shipping industry. Maritime Policy \& Management 29(3): 303-330.

Kavussanos, M.G. and Marcoulis, S.N. (2000) The stock market perception of industry risk through the utilisation of a general multifactor model. International Journal of Transport Economics/Rivista internazionale di economia dei trasporti, pp.77-98.

Kavussanos, M.G. and Tsouknidis, D.A. (2014) The determinants of credit spreads changes in global shipping bonds. Transportation Research Part E: Logistics and Transportation Review 70: 55-75.

Kavussanos, M.G. and Visvikis, I.D. (2006) Derivatives and risk management in shipping. London: Witherby Seamanship International.

Leggate, H.K. (2000) A European perspective on bond finance for the maritime industry. Maritime Policy \& Management 27(4): 353-362.

Macpherson, A., and Holt, R. (2007) Knowledge, learning and small firm growth: A systematic review of the evidence. Research Policy 36: 172-192.

Merikas, A., Gounopoulos, D. and Karli, C. (2010) Market performance of US-listed Shipping IPOs. Maritime Economics \& Logistics 12(1): 36-64.

Merikas, A., Sigalas, C. and Drobetz, W. (2011) The shipping corporate risk trade-off hypothesis. Marine Money 27(6): 40-43. 
Merton, R.C. (1973) Theory of rational option pricing. The Bell Journal of Economics and Management Science 4(1): 141-183.

Miller, E.M. (1977) Risk, uncertainty, and divergence of opinion. The Journal of Finance 32(4): 1151-1168.

Mourdoukoutas, P. and Stefanidis, A. (2009) To list or not to list: expectations versus reality for Greek shipping IPOs. South East European Journal of Economics and Business 4(1): 125134.

Myers, S.C. (1977) Determinants of corporate borrowing. Journal of Financial Economics 5(2): 147-175.

Myers, S.C. (1984) The capital structure puzzle. The Journal of Finance 39(3): 574-592.

Myers, S.C. (2001) Capital structure. The Journal of Economic Perspectives 15(2): 81-102.

Myers, S.C. and Majluf, N.S. (1984) Corporate financing and investment decisions when firms have information that investors do not have. Journal of Financial Economics 13(2): 187-221.

Panayides, P.M. and Gong, X. (2002) The stock market reaction to merger and acquisition announcements in liner shipping. International Journal of Maritime Economics 4(1): 55-80.

Panayides, P.M. and Gong, X. (2002) Consolidation, Mergers and Acquisitions in the Shipping Industry. The Handbook of Maritime Economics and Business, pp. 598-620, London: LLP.

Petticrew, M., and Roberts, H. (2008) Systematic Reviews in the Social Sciences: A Practical Guide, Malden MA: Blackwell Publishing Ltd.

Roll, R. (1986) The hubris hypothesis of corporate takeovers. Journal of Business 59(2): 197216.

Sambracos, E. and Maniati, M. (2013) Shipping Market Financing: Special Features \& the Impact of Basel III. Available at SSRN 2337919.

Samitas, A.G. and Kenourgios, D.F. (2007) Impact of mergers and acquisitions on stock returns of tramp shipping firms. International Journal of Financial Services Management, 2(4): 327-343.

Solesvik, M.Z. and Westhead, P. (2010) Partner selection for strategic alliances: case study insights from the maritime industry. Industrial Management \& Data Systems 110(6): 841860.

Strandenes, S.P. (1984) Price determination in the time charter and second hand markets. Center for Applied Research, Norwegian School of Economics and Business Administration, working paper MU, 6 . 
Syriopoulos, T. (2010) Shipping finance and international capital markets. The Handbook of Maritime Economics and Business, London: Lloyd's List, pp.811-849.

Syriopoulos, T. and Theotokas, I. (2007). Value creation through corporate destruction? Corporate governance in shipping takeovers. Maritime Policy \& Management 34(3): 225242.

Thorpe, R., Holt, R., MacPherson, A. and Pittaway, L. (2005) Using knowledge within small and medium sized firms: A systematic review of the evidence. International Journal of Management Reviews 7: 257-281.

Tranfield, D., Denyer, and Smart, P. (2003) Towards a methodology for developing evidence informed management knowledge by means of systematic review. British Journal of Management 14: 207-222.

Tsolakis, S.D., Cridland, C. and Haralambides, H.E. (2003) Econometric modelling of second-hand ship prices. Maritime Economics \& Logistics 5(4): 347-377.

Yeo, H.J. (2013) Geography of mergers and acquisitions in the container shipping industry. The Asian Journal of Shipping and Logistics 29(3): 291-314. 


\section{APPENDIX A}

\section{$\underline{\text { A.1 }}$}

Transportation Research Part B, Transportation Research Part E, Transport Reviews, Maritime Policy and Management, Economics of Transportation, Transportation, Maritime Economics and Logistics (formerly International Journal of Maritime Economics), International Journal of Shipping and Transport Logistics, Research in Transportation Economics, Transportation Journal, Asian Journal of Shipping and Logistics, Marine Money Offshore, Munich Personal RePEc Archive.

\section{$\underline{\text { A.2 }}$}

Journal of Finance, Review of Financial Studies, Journal of Financial Economics, Journal of Accounting and Economics, Review of Finance, European Economic Review, Journal of World Business, The Quarterly Review of Economics and Finance, International Journal of Business in Society, Industrial Management and Data Systems, The American Economic Review, Journal of Alternative Investments, Journal of Applied Corporate Finance, International Journal of Financial Services Management, Applied Economics, South East European Journal of Economics and Business, Journal of Applied Business Research, Eurasian Business Review.

\section{$\underline{\mathrm{A} .3}$}

Maritime Economics, Shipping Finance, The Handbook of Maritime Economics and Business, The International Handbook of Maritime Economics, The Blackwell Companion to Maritime Economics, Derivatives and Risk Management in Shipping. 